\title{
Jan Hauke
}

Uniwersytet im. Adama Mickiewicza w Poznaniu

Instytut Geografii Spoteczno-Ekonomicznej i Gospodarki Przestrzennej

Zakład Analizy Regionalnej

e-mail: jhauke@amu.edu.pl

\section{Entropijne porównanie nierówności regionalnych postsocjalistycznych państw członkowskich UE w latach 2000 i 2014}

\begin{abstract}
Zarys treści: $\mathrm{W}$ artykule przedstawiono badanie zmian w zróżnicowaniu regionalnym 11 postsocjalistycznych państw członkowskich UE w latach 2000-2014 w oparciu o entropijną statystykę Shannona i algorytm opracowany przez Semple'a i Gauthiera. Praca stanowi kontynuację rozważań przedstawianych przez Czyż i Hauke (2015) w odniesieniu do Polski. Analizę przeprowadzono na podstawie zmian wartości produktu krajowego brutto (PKB) per capita w układzie 218 regionów. Regiony te są częściowo skorygowanymi przez połączenia jednostkami statystycznymi NUTS3. Zostały one wyznaczone przez Perdała (2018).
\end{abstract}

Słowa kluczowe: entropijna miara nierówności, algorytm dekompozycji nierówności regionalnych, zmiany w nierównościach, kraje postsocjalistyczne

\section{Wprowadzenie}

Jak zauważyli w swych pracach Czyż i Hauke (2015a, b), istotnym problemem rozwoju społeczno-gospodarczego jest utrzymujące się, a nawet pogłębiające zróżnicowanie przestrzenne występujące $\mathrm{w}$ ujęciu regionalnym. Nierówności regionalne wpływają negatywnie (hamująco) na procesy rozwoju (Ezcurra 2007). Powodują występowanie silnych kontrastów w poziomie życia ludności, które prowadzą do napięć i konfliktów społecznych, różnicują zdolność regionów do podejmowania własnych działań na rzecz rozwoju, ograniczają możliwość nawiązywania współpracy międzyregionalnej. W krajach Unii Europejskiej głównym celem polityki regionalnej jest osiągnięcie wewnętrznej spójności ekonomicznej i społecznej przez redukcję nierówności regionalnych.

Skuteczność zmodyfikowanej unijnej polityki regionalnej, wprowadzającej nowe rodzaje narzędzi, które mogą pomóc w pobudzaniu rozwoju regionów 
i zagwarantują ich spójność (European Comission 2014), jest naturalnie interesującym obiektem badań naukowych. Istotnym wskaźnikiem używanym w takich badaniach jest poziom nierówności regionalnych. W oparciu o miarę entropii (uwzględniającej rozkład przestrzenny - regiony w krajach) poziom ten badany jest w odniesieniu do różnych krajów unijnych i różnych okresów czasowych (patrz m.in. Simonescu 2014 oraz Fedayev i in. 2017). W pracy przyjmuje się PKB per capita jako „gotowy” wskaźnik, dostępny w statystyce oficjalnej. Czyż (2002, 2012) analizowała ułomności, zalety i modyfikacje tego wskaźnika. Pomimo pewnych ograniczeń ciągle pozostaje on jednak najczęściej stosowanym wskaźnikiem poziomu rozwoju $\mathrm{w}$ analizie regionalnej obok wprowadzanych nowych wskaźników społeczno-gospodarczych (Blakely, Bradshaw 2002, Kudrycka 2014). W badaniach dotyczących wielu krajów naturalne wydaje się odnoszenie się do postaci PKB per capita wyrażonego w standardzie siły nabywczej (ang. purchasing power standard - PPS) i w takiej formie jest on używany w niniejszej pracy.

Celem niniejszego artykułu jest użycie metody entropii przestrzennej w badaniu stanu i zmian w kształtowaniu się zróżnicowania regionalnego poziomu rozwoju społeczno-gospodarczego postsocjalistycznych państw członkowskich UE w latach 2000-2014 na podstawie zmian PKB per capita.

\section{Metoda badawcza}

Precyzyjny opis metody badawczej użytej w pracy został przedstawiony w pracach Czyż Hauke (2015a, b). W niniejszej pracy metoda ta zostanie scharakteryzowana w skróconej wersji bazując na tym opisie.

Entropia jest miarą stopnia niepewności w rozkładzie prawdopodobieństwa zmiennych losowych. Pojęcie entropii powstało na gruncie termodynamiki i znalazło zastosowanie w wielu dziedzinach nauki. Do teorii informacji pojęcie entropii wprowadził Shannon (1948).

W geografii, w tym również w geografii społeczno-ekonomicznej, entropia jest stosowana jako miara uporządkowania przestrzennego lub jednorodności badanego systemu empirycznego. Maksimum entropii oznacza maksimum nieporządku przestrzennego, minimum entropii - całkowite uporządkowanie systemu.

W badaniu nierówności regionalnych jako pierwsi wprowadzili metodę entropii Semple i Gauthier (1972). Istotną rolę w dalszym rozwinięciu koncepcji geograficznej entropii odgrywają prace Wilsona $(1967,1970,2010)$ i Batty (2010). W literaturze polskiej metodę entropii w ekonometrii przestrzennej używa Wędrowska $(2010,2012)$ oraz w analizie konwergencji rozwoju regionalnego Kudrycka (2014).

Według Shannona (1948) informację uzyskaną w wyniku pojawienia się zdarzenia losowego określa funkcja prawdopodobieństwa $p$ o postaci $\log _{2} \frac{1}{p}=-\log _{2} p$ która może być również ujmowana jako miara niepewności wystąpienia zdarzenia (użycie logarytmu przy podstawie 2 ma uzasadnienie informatyczne, choć nie 
ma przeszkód formalnych dla wykorzystania tej funkcji z logarytmami o innych podstawach).

Dla szeregu zdarzeń losowych $x_{i}, i=1,2, \ldots . \mathrm{n}, \mathrm{z}$ prawdopodobieństwami $p\left(x_{i}\right)$ spełniających warunek $0 \leq p\left(x_{i}\right) \leq 1, \sum_{i=1}^{n} p\left(x_{i}\right)=1$ Shannon (1948) określił średnią informację, czyli entropię $H(x)$ jako wartość oczekiwaną (przeciętna) tych prawdopodobieństw wyrażoną wzorem:

$$
H(x)=\sum_{i=1}^{n} p\left(x_{i}\right) \log _{2} p\left(x_{i}\right) .
$$

Funkcja entropii Shannona $H(x)$ przyjmuje wartości z przedziału od 0 do $\log _{2} n$. Maksimum $H(x)$ oznacza całkowitą jednorodność (równomierny rozkład). Ze względu na naturalne dążenie do tego, by opisywane zjawisko niejednorodności narastające w skali było zgodne z rosnącymi wartościami wskaźnika opisującego niejednorodności zamiast $H(x)$ używa się miary nierówności $I(x)$, określonej równaniem:

$$
I(x)=H(x)_{\max }-H(x)=\sum_{i=1}^{n} p\left(x_{i}\right) \log _{2}\left[n p\left(x_{i}\right)\right]
$$

przy czym

$$
0 \leq I(x) \leq \log _{2} n
$$

gdzie wartość $I(x)=0$ wskazuje na brak nierówności (rozkład równomierny), a wartość $I(x)=\log _{2} n$ oznacza maksymalną nierównomierność występowania zdarzenia $x$.

Semple i Gauthier (1972) oraz Gauthier i Semple (1974) zaproponowali użycie entropii $\mathrm{w}$ analizie nierówności w postaci:

$$
H(x)=-\sum_{r=1}^{R}\left[\sum_{r \in S_{r}} p\left(x_{i}\right) \log _{2}\left(x_{i}\right)\right],
$$

gdzie:

$S_{r}=r$-ty region $S, r=1,2, \ldots, R$

$n_{r}-$ liczba subregionów $\mathrm{w}$ regionie $r$,

$\mathrm{n}=\sum_{\mathrm{r}=1}^{\mathrm{R}} n_{r}=$ całkowita liczba subregionów,

$x_{i}=$ wartość zmiennej $x \mathrm{w}$ subregionie $i$.

Pozwoliło to na dekompozycję entropii $H(x)$ na dwa składniki w postaci: 


$$
H(x)=-\sum_{r=1}^{R} p\left(x_{r}\right) \log _{2} p\left(x_{r}\right)-\sum_{r=1}^{R} p\left(x_{r}\right)\left[\sum_{i \in S_{r}} \frac{p\left(x_{i}\right)}{p\left(x_{r}\right)} \log _{2} \frac{p\left(x_{i}\right)}{p\left(x_{r}\right)}\right] .
$$

Pierwszy składnik jest entropią zmiennej $x \mathrm{w}$ układzie międzyregionalnym, drugi składnik jest ważoną średnią entropią wewnątrzregionalną. To z kolei prowadzi do statystyki nierówności:

$$
I(x)=\sum_{r=1}^{R} p\left(x_{r}\right) \log _{2} \frac{p\left(x_{r}\right)}{\frac{n_{r}}{n}}+\sum_{r=1}^{R} p\left(x_{r}\right)\left[\sum_{i \in S_{r}} \frac{p\left(x_{i}\right)}{p\left(x_{r}\right)} \log _{2} \frac{\frac{p\left(x_{i}\right)}{\frac{p\left(x_{r}\right)}{n_{r}}}}{]}\right.
$$

Pierwszy człon równania (*) mierzy nierówności międzyregionalne. Jest równy zeru, gdy $p\left(x_{r}\right)=\frac{n_{r}}{n}$. Ta sytuacja występuje tylko wtedy, gdy wartość x dla każdego $z$ regionów jest taka sama jak średnia $z$ wartości $x$ dla regionów. Drugi człon jest miarą nierówności wewnątrzregionalnych. Jest równy zeru, gdy $\frac{p\left(x_{i}\right)}{p\left(x_{r}\right)}=\frac{1}{n_{r}}$. Ta sytuacja występuje tylko wtedy, gdy wszystkie $p x_{i}$ dla subregionów są równe wewnątrz ich regionów. Powyższa miara pozwala nie tylko wyróżnić dwa składniki zróżnicowania systemu regionalnego: nierówności międzyregionalne i nierówności wewnątrzregionalne ale także określić ich relacje.

\section{Analiza empiryczna}

W badaniu zróżnicowania regionalnego unijnych krajów postsocjalistycznych w latach 2000-2014 z zastosowaniem entropijnej miary nierówności układ podstawowych jednostek tworzy 218 regionów. Regiony te stanowią jednostki statystyczne NUTS3, częściowo skorygowane przez połączenia, wprowadzone przez Perdała (2018). W przypadku jednostek NUTS3 w postaci miast wydzielonych (Budapeszt, Katowice, Kraków, Lublana, Łódź, Poznań, Praga, Ryga, Sofia, Szczecin, Trójmiasto, Warszawa, Wrocław, Zagrzeb) zostały one połączone z jednostkami je otaczającymi (masy tych jednostek sumowano). Takie potraktowanie regionów badanych krajów postsocjalistycznych podyktowane było chęcią przeprowadzenia analizy na danych identycznych $z$ danymi użytymi w modelu ilorazu potencjałów w pracy Perdała (2018). Stwarza to możliwość porównania uzyskanych wyników.

Dane pochodzą ze źródeł Eurostatu i dotyczą lat 2000 oraz 2014. Wybór zakresu czasowego badań łączy się z możliwością uchwycenia zmian w zróżnicowaniu regionalnym, będących efektem realizacji w nowych państwach członkowskich UE po roku 2004 nowej polityki regionalnej, już w ramach UE. Wtedy do 
UE przystąpiło osiem $z$ badanych krajów postsocjalistycznych. Jedynie Rumunia, Bułgaria i Chorwacja wstąpiły do UE później (odpowiednio w 2007, 2007 oraz 2013 r.). Badane regiony wchodzą w skład 11 krajów. Kraje mają różną liczbę regionów, od 5 (Słowenia) do 60 (Polska), które tworzą ich wewnętrzną strukturę.

Jako miarę rozwoju społeczno-gospodarczego krajów i regionów stosuje się dochód ważony liczbą ludności, czyli wielkość względną. Przyjmuje się, że przeliczony na mieszkańca dochód kraju i dochód regionu określa poziom ich rozwoju społeczno-gospodarczego. W latach 2000-2014 badane kraje i regiony wykazują wzrost dochodu na mieszkańca (patrz Perdał 2018, tab. 2). W regionach wzrost dochodu na mieszkańca jest często połączony $z$ fluktuacjami w rozwoju demograficznym, podobnie jak to zauważono w pracy Czyż i Hauke (2015a), w odniesieniu do Polski.

W postępowaniu badawczym celem określenia zróżnicowania $\mathrm{w}$ systemie regionalnym postsocjalistycznych krajów będących członkami UE stosuje się entropijną miarę nierówności $I(x)$ i wprowadza się procedurę ustalania nierówności wewnątrz- i międzykrajowych na podstawie dochodu per capita. Prawdopodobieństwo występowania zjawiska (dochodu per capita) w regionie równa się $p\left(x_{r}\right)$, a wewnątrz regionu $\frac{p\left(x_{i}\right)}{p\left(x_{r}\right)}$, gdzie $x_{i}$ oznacza dochód $(x)$ w i-tym regionie kraju $r$.

Procedura obliczania entropijnej miary nierówności jest realizowana zgodnie $z$ algorytmem Semple'a i Gauthier (1972) na podstawie wzoru $\left({ }^{*}\right)$, gdzie $R=11$ oznacza liczbę krajów, a $n_{r}$ określa liczebność regionów w poszczególnych krajach.

Wskaźnik nierówności obliczony na podstawie PKB per capita (czyli dochodu ważonego liczbą ludności) - I(x), rozpatruje się w postaci ogólnego wskaźnika nierówności wszystkich krajów postsocjalistycznych i jego dekompozycji na wskaźnik nierówności w $I(x)_{\text {inter }}$ i wskaźnik nierówności wewnątrzkrajowych, regionalnych $I(x)_{\text {intra }}$. Podstawę $\mathrm{w}$ obliczeniach (jak to opisano $\mathrm{w}$ metodzie) stanowiły prawdopodobieństwa wyrażające proporcje dochodu PKB per capita dla poszczególnych regionów względem ich sumy liczonej, odpowiednio, dla roku 2000 oraz 2014.

Wartości poszczególnych miar nierówności, tj.: ogólna nierówność dla wszystkich badanych krajów w układzie 218 regionów, nierówności między krajami w układzie 11 krajów, nierówności wewnątrzkrajowe w układach 5-60 regionów zawiera tabela 1.

Tabela 1. Entropijna miara nierówności krajów postsocjalistycznych na podstawie dochodu per capita $I(x)$ w latach 2000 i 2014

\begin{tabular}{cccc}
\hline Rok & $\begin{array}{c}\text { Ogólna nierówność } \\
I(x)\end{array}$ & $\begin{array}{c}\text { Nierówności } \\
\text { wewnątrzregionalne } \\
I(x)_{\text {intra }}\end{array}$ & $\begin{array}{c}\text { Nierówności } \\
\text { międzyregionalne } \\
I(x)_{\text {inter }}\end{array}$ \\
\hline 2000 & 0,139 & 0,051 & 0,088 \\
2014 & 0,109 & 0,073 & 0,036 \\
\hline
\end{tabular}

Źródło: obliczenia własne na podstawie danych Eurostatu. 
W okresie od 2000 do 2014 wartość wskaźnika $I(x)$ zmniejszyła się. W roku 2000 wynosiła 0,139 i stanowiła $1,79 \%$ wartości maksymalnej, podczas gdy w roku 2014 wynosiła 0,109 i stanowiła 1,40\% wartości maksymalnej.

W roku 2000 głównym składnikiem nierówności w układzie tej grupy krajów były nierówności między krajami. Stanowiły $63,8 \%$ ogólnych nierówności. Z kolei w roku 2014 nastąpiło odwrócenie zjawiska i głównym składnikiem (w proporcji $66,7 \%$ ) okazały się nierówności wewnątrz krajów (regionalne).

Mniejszy udział nierówności między krajami w kształtowaniu ogólnych nierówności świadczył o stosukowo słabym, choć nasilającym się w czasie udziale nierówności międzyregionalnych $\mathrm{w}$ nierównościach krajowych. W tabeli 2 przedstawiono wartości składowych wskaźników $I(x)_{\text {inter }}$ oraz $I(x)_{\text {intra }}$ "wniesione" przez poszczególne kraje. Należy zwrócić uwagę na fakt, że wśród składowych poszczególnych krajów wnoszonych do wskaźnika $I(x)_{\text {intra }}$ (patrz tab. 2) ujemne wartości odnotowano w przypadku pięciu krajów (Bułgarii, Litwy, Łotwy, Estonii i Rumunii) w roku 2000 oraz czterech krajów (Bułgarii, Chorwacji, Łotwy i Rumunii) w roku 2014. Łączny ładunek tej ujemności był większy w pierwszym przypadku. Świadczy to o dużej polaryzacji wpływu badanych krajów na ogólny poziom nierówności.

Szczegółową dynamikę zmian wartości składowej $I(x)_{\text {intra }}$ w roku 2014 względem roku 2000 przedstawiono w tabeli 3, gdzie zamieszczono także wkłady procentowe badanych krajów. Należy podkreślić, że pomimo spadku ogólnej wartości wskaźnika $I(x)$ wartość składowej $I(x)_{\text {intra }}$ wzrosła z 0,051 w roku 2000 do $0,073 \mathrm{w}$ roku 2014 (patrz tab. 1). Wynikało to $\mathrm{z}$ istotnego wzrostu wkładu „wniesionego” przez tak duże kraje, jak Rumunia (wzrost o 6,3\%) i Polska (wzrost o 5,2\%). Oba te kraje mają duże liczby regionów (odpowiednio 60 i 41), co oczywiście sprzyja większemu zróżnicowaniu wewnętrznemu w tych krajach, stanowiąc jednocześnie zobowiązanie do uważniejszej polityki regionalnej. Jedynym krajem, w którym nie nastąpiła względna zmiana wkładu, są Czechy, zaś

Tabela 2. Składowe wartości wskaźnika nierówności regionalnych w 2000 i 2014 r.

\begin{tabular}{|c|c|c|c|c|c|}
\hline \multirow{2}{*}{ Państwo } & \multirow{2}{*}{$\begin{array}{l}\text { Liczba } \\
\text { regionów }\end{array}$} & \multicolumn{2}{|c|}{$I(x)_{\text {inter }}$} & \multicolumn{2}{|c|}{$I(x)_{\text {intra }}$} \\
\hline & & 2000 & 2014 & 2000 & 2014 \\
\hline Bułgaria & 26 & $-0,050159$ & $-0,050271$ & 0,003182 & 0,006313 \\
\hline Chorwacja & 20 & 0,014539 & $-0,013439$ & 0,004486 & 0,004688 \\
\hline Czechy & 13 & 0,076239 & 0,041883 & 0,002395 & 0,002377 \\
\hline Estonia & 5 & $-0,002402$ & 0,004997 & 0,001842 & 0,002431 \\
\hline Litwa & 10 & $-0,009417$ & 0,009563 & 0,002026 & 0,003351 \\
\hline Łotwa & 5 & $-0,007303$ & $-0,002881$ & 0,001783 & 0,002115 \\
\hline Polska & 60 & 0,022743 & 0,024310 & 0,014151 & 0,019241 \\
\hline Rumunia & 41 & $-0,084744$ & $-0,040160$ & 0,007125 & 0,015331 \\
\hline Słowacja & 8 & 0,020243 & 0,030460 & 0,005601 & 0,008843 \\
\hline Słowenia & 11 & 0,089241 & 0,031202 & 0,001849 & 0,001593 \\
\hline Węgry & 19 & 0,019454 & 0,000476 & 0,005815 & 0,006104 \\
\hline
\end{tabular}

W tabeli kolorem szarym zaznaczono kraje wnoszące do wskaźnika $I(x)_{\text {intra }}$ ujemny wkład.

Źródło: obliczenia i opracowanie własne na podstawie danych Eurostatu. 
Tabela 3. Dynamika zmian składowej $I(x)_{\text {intra }}$ wartości wskaźnika nierówności regionalnych w 2000 i 2014 r.

\begin{tabular}{lccc}
\hline \multirow{2}{*}{ Państwo } & Ważone wartości względne & $I(x)_{\text {intra }}(\%)$ & $\begin{array}{c}\text { Dynamika } \\
(\% \text { przyrosty) }\end{array}$ \\
\cline { 2 - 4 } & 2000 & 2014 & $2014-2000$ \\
\hline Bułgaria & 1,76 & 3,49 & 1,73 \\
Chorwacja & 2,08 & 2,17 & 0,09 \\
Czechy & 0,84 & 0,84 & $-0,01$ \\
Estonia & 0,40 & 0,52 & 0,13 \\
Litwa & 0,61 & 1,01 & 0,40 \\
Łotwa & 0,38 & 0,46 & 0,07 \\
Polska & 14,37 & 19,54 & 5,17 \\
Rumunia & 5,45 & 11,73 & 6,28 \\
Słowacja & 1,49 & 2,36 & 0,86 \\
Słowenia & 0,59 & 0,51 & $-0,08$ \\
Węgry & 2,60 & 2,73 & 0,13 \\
\hline W
\end{tabular}

W tabeli kolorem szarym zaznaczono kraje, dla których nastąpił spadek wartości.

Źródło: obliczenia i opracowanie własne na podstawie danych Eurostatu.

w Słowenii zaobserwowano nawet niewielki spadek (dane te zaznaczono w tab. 3 kolorem szarym).

Dekompozycja nierówności jest związana z określonym rozkładem prawdopodobieństwa dochodu w układzie krajów i w układzie regionów. Wartości prawdopodobieństw [stanowiących podstawę obliczeń entropijnej miary nierówności i opisanych $\mathrm{w}$ formule $(*)$ ] dla wszystkich analizowanych regionów zostały podzielone na trzy grupy za pomocą analizy skupień w oparciu o metodę Warda (1963) z użyciem odległości euklidesowej (co jest naturalne w przypadku jednej zmiennej). Przyjęty podział uwzględniający trzy grupy odnosi się do najczęściej stosowanej skali: słaby - średni - silny. Należy podkreślić, że podział ma charakter względny, co polega na wyznaczaniu różnych granic podziałowych dla danych z roku 2000 oraz z roku 2014. W roku 2000 pierwsza (najsłabsza ekonomicznie) grupa $z$ prawdopodobieństwami w przedziale od 0 do 0,00550 zawiera 167 regionów, druga z prawdopodobieństwami w przedziale od 0,00550 do 0,00900

Tabela 4. Wybrane prawdopodobieństwa ( $\mathrm{p}>0,00900)$ dochodu w układzie krajów i w układzie regionów w roku 2000 (regiony najsilniejsze ekonomicznie)

\begin{tabular}{llc}
\hline Kraj & Region & Prawdopodobieństwo \\
\hline Słowacja & Bratislavský kraj & 0,01296 \\
Czechy & Praha Agglomeration & 0,01272 \\
Słowenia & Lubljana Agglomeration & 0,01249 \\
Polska & Warszawa Agglomeration & 0,01111 \\
Słowenia & Obalno-kraska & 0,01002 \\
Węgry & Budapest Agglomeration & 0,00966 \\
Słowenia & Goriska & 0,00925 \\
Słowenia & Jugovzhodna Slovenija & 0,00925 \\
\hline
\end{tabular}

Źródło: obliczenia własne na podstawie danych Eurostatu. 
Tabela 5. Wybrane prawdopodobieństwa ( $\mathrm{p}>0,00800)$ dochodu w układzie krajów i w układzie regionów w roku 2014 (regiony najsilniejsze ekonomicznie)

\begin{tabular}{llc}
\hline Kraj & Region & Prawdopodobieństwo \\
\hline Słowacja & Bratislavský kraj & 0,01600 \\
Polska & Warszawa Agglomeration & 0,01165 \\
Rumunia & Bucuresti Agglomeration & 0,01098 \\
Czechy & Praha Agglomeration & 0,01079 \\
Słowenia & Lubljana Agglomeration & 0,00940 \\
Estonia & Põhja-Eesti & 0,00924 \\
Litwa & Vilniaus apskritis & 0,00924 \\
Węgry & Budapest Agglomeration & 0,00904 \\
Polska & Poznań Agglomeration & 0,00901 \\
Polska & Płocki & 0,00855 \\
Polska & Legnicko-Głogowski & 0,00852 \\
\hline
\end{tabular}
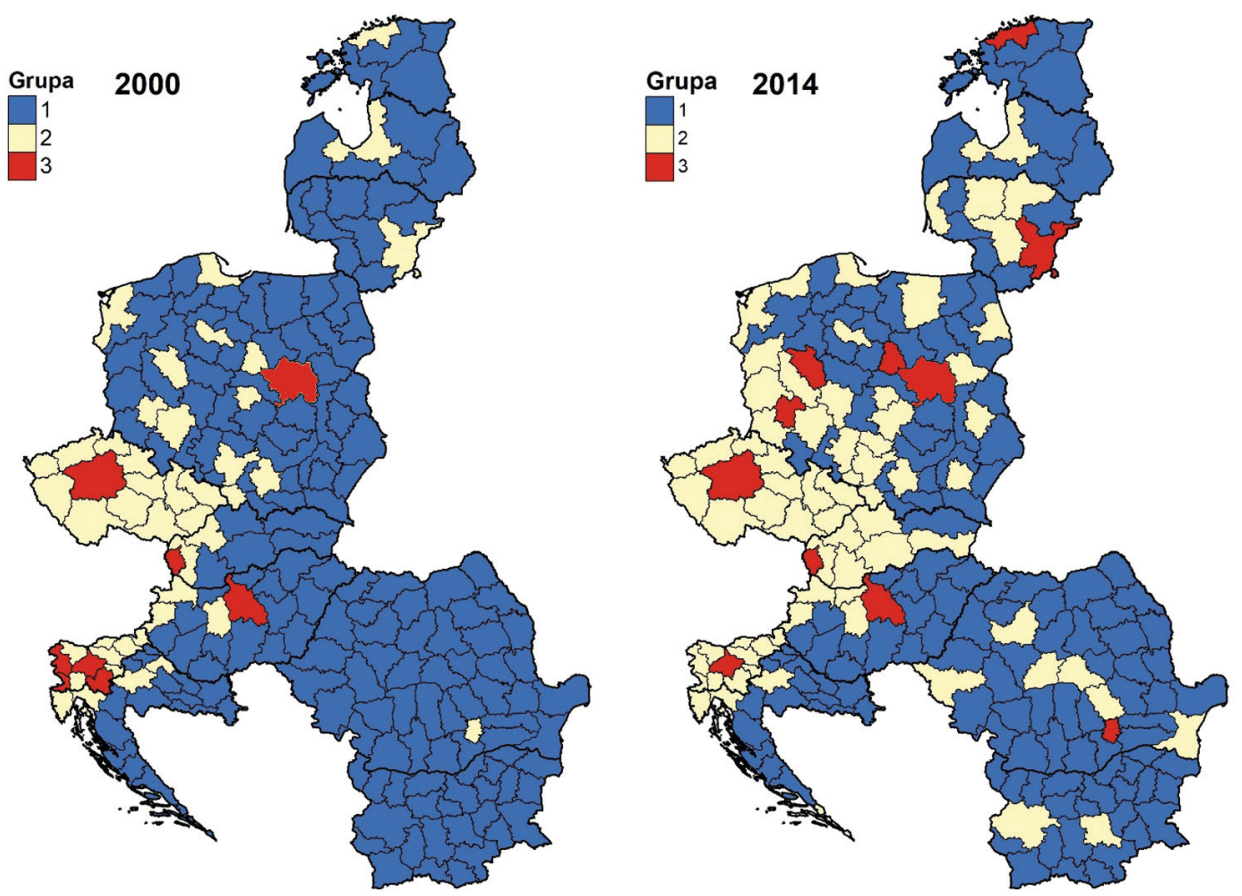

Ryc. 1. Przestrzenne zróżnicowanie prawdopodobieństw wyrażających proporcje dochodu PKB per capita dla poszczególnych badanych regionów względem ich sumy liczonej dla roku: a) 2000, b) 2014. Grupy: 1 - regiony najsłabsze ekonomicznie, 2 - regiony o średnim poziomie, 3 - regiony najsilniejsze

Źródło: wykonał R. Perdał na podstawie obliczeń autora. 
obejmuje 43 regiony. Grupa trzecia (najsilniejsza ekonomicznie) z prawdopodobieństwami powyżej 0,00900 zawiera 8 regionów (wyszczególniono je w tab. 4). Rozkład przestrzenny wydzielonych grup regionów przedstawiono na rycinie la.

W roku 2014 pierwsza (najsłabsza ekonomicznie) grupa z prawdopodobieństwami w przedziale od 0 do 0,00465 zawiera 135 regionów, druga z prawdopodobieństwami w przedziale od 0,00465 do 0,00800 - 72 regiony. Grupa trzecia (najsilniejsza ekonomicznie) z prawdopodobieństwami powyżej 0,00800 obejmuje 11 regionów (wyszczególniono je w tab. 5). Rozkład przestrzenny tych grup regionów przedstawiono na rycinie $1 \mathrm{~b}$.

Komentując rezultaty prezentowanych podziałów, należy zwrócić uwagę na wyraźne zmniejszenie się liczebności regionów pierwszej (najsłabszej ekonomicznie) grupy ze $167 \mathrm{w}$ roku 2000 do $135 \mathrm{w}$ roku 2014. Z kolei liczebność W grupie trzeciej (najsilniejszej pod względem ekonomicznym) zwiększyła się nieznacznie ( $z 8$ do 11), w tej grupie jako dominującej pod względem poziomu rozwoju społeczno-gospodarczego utrzymują się przede wszystkim regiony składające się głównie $z$ aglomeracji ze stolicami badanych krajów, co jest zgodne z wynikami otrzymanymi przez Perdała (2018).

\section{Wnioski końcowe}

Badanie zróżnicowania poziomu rozwoju regionalnego społeczno-gospodarczego postsocjalistycznych państw członkowskich UE w latach 2000-2014 w oparciu o entropijną miarę nierówności prowadzi do następujących ustaleń i wniosków:

1. Nierówności w grupie 11 krajów postsocjalistycznych (w układzie 218 regionów), określone na podstawie rozkładu dochodu per capita, zmniejszyły się w badanym okresie o $22 \%$ względem wartości wyjściowej, co wskazuje na ogólny pozytywny efekt unijnej regionalnej polityki spójności. Dodatkowym wzmocnieniem powyższej tezy jest fakt, że liczebność regionów w grupie najsłabszych ekonomicznie istotnie się zmniejszyła w latach 2000-2014.

2. W latach 2000-2014 w kształtowaniu nierówności regionalnych zaobserwowano istotną zmianę $\mathrm{w}$ proporcji udziału składowych zdekomponowanego wskaźnika nierówności krajowych. Podczas gdy w roku 2000 znacznie większy udział mają nierówności między krajami (64\%), w roku 2014 ich udział stanowi tylko 33\% łącznej wartości wskaźnika $I(x)$. Wynika z tego, że ewentualna korekta unijnej polityki regionalnej powinna koncentrować się na wsparciu odpowiedniej, bardziej zrównoważonej polityki regionalnej w poszczególnych krajach, przynajmniej w odniesieniu do unijnych krajów postsocjalistycznych. Należy też zwrócić uwagę na ciągle dominujące regiony stołeczne względem pozostałych regionów. Jedynie w przypadku Polski do grupy najsilniejszych regionów (poza regionem stołecznym) w roku 2014 dołączyły trzy regiony (aglomeracja poznańska, region płocki oraz region legnicko-głogowski). 


\section{Literatura}

Batty M. 2010. Space, scale, and scaling in entropy maximizing. Geographical Analysis, 42: 395-421. Blakely E.J., Bradshaw T.K. 2002. Planning local economic development. Theory and practice. Sage Publication, Thousand Oaks, California.

Czyż T. 2002. Zastosowanie modelu potencjału w analizie zróżnicowania regionalnego Polski. Studia Regionalne i Lokalne, 2-3: 5-14.

Czyż T. 2012. Poziom rozwoju społeczno-gospodarczego Polski w ujęciu subregionalnym. Przegląd Geograficzny, 84, 2: 219-236.

Czyż. T., Hauke J. 2015a. Entropijna miara nierówności w badaniach regionalnych. Rozwój Regionalny i Polityka Regionalna, 32: 17-30.

Czyż T., Hauke J. 2015b. Spatial entropy in regional analysis. Quaestiones Geographicae, 34(4): 30-47.

European Commision EU 2014. Investment for jobs and growth. Promoting development and good governance in EU regions and cities. Six report on economic, social and territorial cohesion. Region and Urban Commission, Brussels.

Ezcurra R. 2007. In income inequality harmful for regional growth? Evidence from the European Union. Urban Studies, 44, 10: 1953-1971.

Fedayev A., Durkalić D., Arsić M. 2017. Convergence of EU countries in meeting the europe 2020 strategy goals. 7th International Symposium on Environmental and Material Flow Management - EMFM 2017. Book of Proceedings, s. 110-120. University of Belgrade, Technical Faculty in Bor.

Kudrycka I. 2014. Analiza konwergencji rozwoju regionalnego w Polsce w latach 2001-2012. Acta Universitatis Lodziensis, Folia Oeconomica, 6: 51-66.

Gauthier H.L., Semple R.K. 1974. Trends in regional inequalities in the Brazilian economy 19471966. [W:] R.S. Thoman (red.), Methodology and case studies. Vol. I. Proceedings of the Commission on Regional Aspects of Development of the IGU. Hayword, California, USA, s. 249-266.

Perdał R. 2018. Zróżnicowanie regionalne postsocjalistycznych państw członkowskich UE w latach 2000-2014. Rozwój Regionalny i Polityka Regionalna, 41: 83-100.

Semple R.K., Gauthier H.L. 1972. Spatial-temporal trends in income inequalities in Brasil. Geographical Analysis, 2: 189-179.

Shannon C.E. 1948. A mathematical theory of communication. Bell System Technical Journal, 27: 379-423, 623-656.

Simonescu M. 2014. The economic convergence in European Union based on concentration and entropy approach. EuroEconomica, 1(33): 31-42.

Ward J.H. 1963. Hierarchical Grouping to Optimize an Objective Function. Journal of the American Statistical Association, 58: 236-244.

Wędrowska E. 2010. Wykorzystanie entropii Shannona i jej uogólnień do badania rozkładu prawdopodobieństwa zmiennej losowej dyskretnej. Przegląd Statystyczny, 4: 39-53.

Wędrowska E. 2012. Miary entropii i dywergencji w analizie struktur. Wydawnictwo UWM, Olsztyn. Wilson A.G. 1967. A statistical theory of spatial distribution models. Transport Research, 1:253-269. Wilson A.G. 2010. Entropy in urban and regional modelling retrospect and prospect. Geographical Analysis, 42: 364-394.

\section{Comparison of regional disparities in post-socialist EU member states in the years 2000-2014 based on entropy measure}

\footnotetext{
Abstract: The article presents comparison of regional disparities in 11 post-socialist EU member states in the years 2000-2014 with the use of Shannon entropy statistics and algorithm developed by Semple and Gauthier. The analysis is based on changes in the value of the gross domestic product (GDP) per capita in 218 regions. These regions, determined by Perdał (2018), are partially corrected (connected), NUTS3 statistical units.
}

Key words: entropy measure of inequality, decomposition algorithm of regional inequalities, changes in regional inequalities, post-socialist countries 